\title{
Problemy współczesnych migracji na przykładzie doświadczeń Polaków w Szkocji
}

\begin{abstract}
This article attempts to reflect on three crucial issues concerning migration research. First of all, we seek the answer to the question: what is a specific problem of migration in sociology and in theoretical and methodological approach? For this purpose we reach to the roots of Polish researches of migrants, by Florian Znaniecki and Józef Chałasiński. Secondly, we try to reconstruct the map of current migration problems as is the effect of reviewing the literature of the subject. We pay particular attention to research on migration issues in the UK. Thirdly, we attempt to present our own research approach to Polish emigrants’ problems by using two basical categories: adaptation and integration. The subject of further empirical investigations will be the factors which facilitate or block these processes.
\end{abstract}

\section{Keywords:}

migration, after access migration, attitudes, values, identity, modernization

1 Tomasz Leszniewski, Katedra Socjologii Edukacji i Pedagogiki Społecznej, Wydział Nauk Pedagogicznych, Uniwersytet Mikołaja Kopernika w Toruniu, Polska, tomaszl@umk.pl.

2 Piotr Krakowiak, Katedra Pracy Socjalnej, Wydział Nauk Pedagogicznych, Uniwersytet Mikołaja Kopernika w Toruniu, Polska, pkrakow@umk.pl.

3 Tomasz Biernat, Wyższa Szkoła Bankowa w Gdańsku, Polska, tomabier@wp.pl. 


\section{WSTĘP}

Socjologiczna obserwacja dotycząca procesów i zjawisk, które mają miejsce we współczesnych społeczeństwach - bez względu na kontynent - pozwala zauważyć rosnące znaczenie mobilności. Proces globalizacji w wymiarze ekonomicznym, politycznym i komunikacyjnym daje możliwość tworzenia relacji społecznych wykraczających poza granice państw narodowych w sposób o wiele łatwiejszy i szybszy. Poszerzanie się struktur społecznych zależności stwarza warunki oraz stanowi czynnik motywacyjny do poszukiwania przez jednostkę miejsca, które opowiada jej oczekiwaniom życiowym.

Trudno kwestionować fakt, że w powyższych warunkach - narastającej mobilności - procesy migracyjne odgrywają ważną rolę w wyznaczaniu cywilizacyjnych przemian. Uczestniczą w tworzeniu kapitału ekonomicznego, generują kulturowe napięcia, polityczne idee, czy też zmiany demograficznych wskaźników. Pokładane są w nich również nadzieje modernizacyjne, związane z reorganizacją na różnych wymiarach - społecznym, kulturowym, ekonomicznym, instytucjonalnym itp. - systemowego porządku. Dotyczy to zarówno przypadków imigracji, jak i reemigracji.

Poniższy tekst jest próbą zarysowania pola problemowego wyłaniającego się w kontekście przygotowanych badań dotyczący polskich emigrantów na terenie Szkocji. Rekonstruuje związane ze sobą trzy fazy poznawczego namysłu nad analizowanym zagadnieniem. Pierwsza stanowi odwołanie się do źródeł socjologicznej refleksji nad problemem emigracji, zwłaszcza do polskiej tradycji badawczej, z przywołaniem kluczowych prac Floriana Znanieckiego (napisanej wraz z Wiliamem Thomasem Chłop polski w Europie i Ameryce) czy Józefa Chałasińskiego (Emigracja jako zjawisko społeczne). Ma to pozwolić na uchwycenie zmienności oraz ciągłości, kontynuacji niektórych właściwości omawianego procesu. Innymi słowy wydłużenie perspektywy czasowej analizy w większym stopniu gwarantuje klarowne uchwycenie dynamiki badanego zjawiska. W fazie drugiej zwraca się uwagę na fakt, że podejmowane inicjatywy badawcze nie dokonują się w próżni, ale wymagają naukowego rozpoznania dotychczasowych - aktualnych - analiz poczynionych przez innych badaczy. Ich przywołanie da możliwość zdefiniowania potencjalnego pola problemowego, które wyznacza orbitę zainteresowań środowiska naukowego odnoszących się do bieżącego problemu emigracji. Z uwagi na cel postawiony przez autorów opisywane zjawisko zostało zawężone do obszaru Wielkiej Brytanii, w granice której trafia znacząca część polskiej emigracji. Dodatkowym argumentem, niewymagającym szczególnych uzasadnień, jest również to, że centralny problem podjętych badań dotyczy Szkocji, będącej częścią Wielkiej 
Brytanii, co w konsekwencji wyznacza społeczno-kulturowy kontekst podjętych analiz. W części trzeciej natomiast zostaną wyrażone hipotezy, które dotyczą problematyki polskiej emigracji na terenie Szkocji, z uwzględnieniem specyfiki badanego problemu.

\section{SIĘGAJĄC DO KORZENI - INSPIRACJE TEORETYCZNO- -METODOLOGICZNE POLSKIMI POCZĄTKAMI SOCJOLOGICZNYCH BADAŃ NAD EMIGRACJĄ}

Trudno nie zgodzić się z zaproponowaną przez Józefa Chałasińskiego w tekście Emigracja jako zjawisko społeczne (1936) genezą problemu emigracji. Podobnie jak inne problemy socjologiczne ma on podłoże praktyczno-polityczne. Odnosi się do konkretnych zjawisk rejestrowanych przez wspólnoty polityczne, gdy mobilność obywateli przekracza granice państwowego systemu. Zatem tego typu ruchliwość z uwagi na realną ingerencję zarówno w porządek społeczny opuszczany, jak i ten docelowy migracji wywołuje znaczące konsekwencje społeczne. Można także uznać, że argument dotyczący praktyczno-politycznej genezy zainteresowania problematyką migracji wytrzymuje próbę czasu, co wskazuje na specyfikę perspektyw poznawczych dociekań współczesnych nauk społecznych. Jako społeczeństwo przyglądamy się ze szczególną uwagą tego typu procesom i zjawiskom, zwłaszcza w momentach historycznych, w których nabierają one na sile.

Tradycja socjologicznych badań nad emigracją zdecydowanie wskazuje na obecność i rolę humanitaryzmu w tworzeniu perspektywy poznawczej. Efektem tego jest zainteresowanie emigrującym człowiekiem jako istotą społeczną, tzn. jednostką, która przekracza granice terytorialne własnej wspólnoty w kontekście pełnionych dotychczas ról społecznych oraz realizowanych funkcji względem swego społecznego otoczenia. Jak pisze Chałasiński, „emigrant może być ujęty socjologicznie w dwojaki sposób: 1. jako pewien kompleks lub system dążności i postaw społecznych wiążących się ściśle ze strukturą społeczną jego grupy, oraz 2. jako «nosiciel» wartości społecznych swojej grupy (lub grup), jako pewien kompleks ról społecznych. Emigracja wprowadza zmiany w tych dwóch ściśle wiążących się ze sobą sferach” (1936, s. 499). Zrozumienie emigracji nie jest zatem możliwe bez analizy sytuacji dwóch środowisk społecznych, a mianowicie wspólnoty „opuszczanej” i docelowej grupy jednostki. Wielość i różnorodność grup naturalnych, do których przynależała i przynależy jednostka w emigracyjnym kontekście powoduje „[...] zjawisko krzyżowania się i konfliktów lojalności” (1936, s. 500). Wiąże się to również z faktem, że więzi i identyfikacja z nie- 
którymi grupami (np. narodem, rodziną) zachowują swoją żywotność, a inne słabną, a wręcz mogą zanikać (np. dotyczące państwa - wymiar polityczny) (zob. Chałasiński, 1936, s. 499).

Refleksja nad zjawiskiem emigracji stara się także ukazać fazowość tego procesu wraz z rozpoznaniem warunków inicjujących wzrost społeczno-przestrzennej mobilności. Otóż koniecznym czynnikiem jest załamanie się postaw utrzymujących dotychczasową społeczną izolację grupy. Skutkuje to możliwością oddzielenia się poszczególnych jednostek od grupy naturalnej. W obliczu coraz częstszych kontaktów i wpływów grup zewnętrznych, następuje istotna zmiana w zakresie wewnętrznych relacji. Dotychczasowa przewaga społecznych sił przyciągania do grupy własnej, zostaje utracona na rzecz ciążenia ku grupie obcej, zewnętrznej. Dotyczy to zarówno sfery ekonomicznej wspólnotowego życia, jak również kulturowej, obyczajowej. W doświadczeniu jednostki opuszczenie własnego dotychczasowego środowiska życia w postaci grup naturalnych staje się możliwe, choć wymaga oczywiście poniesienia pewnych kosztów, trudów związanych z emigracją (Gliwicówna, 1936, s. 502).

Z uwagi na długotrwałość procesu migracyjnego można dostrzec pewnego rodzaju regularności wskazujące na fazowość analizowanego problemu. Odrywanie się od grupy własnej związane z przechodzeniem do innej, nowej grupy naturalnej, dokonuje się w ramach społecznie ustalonych wzorców, które można podzielić na trzy zasadnicze okresy emigracji. Pierwszy okres ma na celu „przełamywanie izolacji społecznej grupy oraz wyznaczenie szlaków wędrowania i miejsc powstania nowych grup, będących «koloniami» grupy macierzystej” (Gliwicówna, 1936, s. 502). Drugi okres związany jest z pojawieniem się rodzinno-sąsiedzkiego charakteru emigracji. Czyli mamy wówczas do czynienia z nieustannym, dwustronnym przepływem ludności między jedną (grupą macierzystą) a drugą grupą (zewnętrzną). Ów fakt związania grupowego procesem mobilności członków zdaje się być niezbędny dla obu środowisk. Na tym etapie instytucjonalizacji procesu emigracji można dostrzec pewne utrwalone już typy relacji i postaw, które nawet w warunkach podejmowanych z zewnętrz prób prawnych ograniczeń nie dają się wyeliminować z życia społecznego. Pojawia się wówczas trzeci okres aktywności migracyjnej skojarzony z jej nielegalnym charakterem - emigracja nielegalna (Gliwicówna, 1936, s. 502).

Zagłębiając się w ukazaną powyżej dynamikę procesów migracyjnych, możemy zauważyć istnienie określonych regularności będących wyrazem zobiektywizowanych postaw i reguł grupowych. Otóż należy uznać, że prekursorami, inicjatorami emigracyjnych zachowań o wiele częściej stają się jednostki lokujące się na peryferiach struktury grupowej, gdyż tylko wówczas, jako jednostki w mniejszym 
stopniu zintegrowane z grupą, są w stanie podjąć ryzyko związane z opuszczeniem grupy własnej i zinternalizowanego świata. Brak silnego związku z grupą redukował znaczenie ewentualnej porażki. Jednak jego emigracyjne działania dopiero w obliczu stawania się „[...] zwyczajem, drogą kariery życiowej i wyróżnienia, sankcjonowaną przez grupę [...]” (Gliwicówna, 1936, s. 508) nabierają społecznego znaczenia i wartości w oczach jednostki.

Sam fakt utrwalenia wzorca emigracyjnego w własnej grupie nie oznacza jeszcze, że tego rodzaju decyzja i działanie stają się pozbawione trudności i istotnych konsekwencji. Za rodzaj strukturalnych ułatwień można uznać fakt pojawienia się mobilności o charakterze sąsiedzko-rodzinnym, która - będąc podstawą silnej więzi miedzy grupą macierzystą a „kolonialną” - ogranicza poziom niepewności osób przemieszczających się w przestrzeni społecznej i geograficznej. Ułatwienie wyjazdu, znalezienia miejsca do zamieszkania i pracy przez osoby znajome, bliskie w nowych, nieznanych okolicznościach sprawia, że decyzje z tym związane następują szybciej i częściej w ramach grupy naturalnej. Silną więź, ścisłą łączność między obiema grupami można uznać za jedną z istotnych przyczyn występowania zjawiska „emigracji na stałe”, gdyż „[...] świadomość ostatecznego opuszczenia kraju nie pokrywa się ze świadomością zrywania z własną grupą” i ,jest dla nich po prostu wędrowaniem w obrębie swojej własnej rozszerzonej grupy” (Gliwicówna, 1936, s. 513). Powoduje to także pojawianie się wzoru, który określamy mianem „emigracji wielokrotnej” oraz „emigracji ciągłej”. Nie bez znaczenia w tym procesie jest ponadto rozwój środków komunikacji, które odpowiadają za ułatwiania i skracanie czasu podróży oraz zmniejszanie dystansu w ramach międzyludzkich relacji.

Postępujący proces emigracyjny powodujący zwiększenia skali zjawiska wywołuje realne konsekwencje w postaci prawnych ograniczeń. Sytuacja ta, w momencie procesu instytucjonalizacji emigracji, ujawnia pojawiające się napięcia i konflikty między różnymi poziomami społecznego systemu. Nielegalność tego zjawiska jest definiowana w kontekście porządku prawnego struktur państwa, ale wciąż pozostaje ono funkcjonalne na poziomie grupy naturalnej. Skutkuje to ewidentną kontestacją reguł prawnych, przy zachowaniu przez grupę wciąż obowiązującego wzoru emigracji. Należy jednak zauważyć, że sytuacja ta generuje równocześnie napięcia i konflikty w obszarze norm i wartości samej grupy macierzystej. Maria Gliwicówna w tekście Drogi emigracji opisuje sytuację, kiedy osoba pełniąca rolę agenta ułatwiającego nielegalny wyjazd traktowana jest przez grupę jako wciąż pełniąca ważną funkcję społeczną, jednakże krytykowana jest za czerpanie z tego osobistych korzyści materialnych (1936). Innymi słowy, czymś złym nie jest w ocenie grupy naturalnej nielegalny przemyt ludzi za granicę, ale wyłącznie 
to, że ktoś na tym korzysta finansowo, pobierając wysokie opłaty, nierzadko przy tym oszukując ludzi i nie wywiązując się z podjętego zadania.

Nawiązanie do kluczowej socjologicznej pracy poświęconej emigracji, a mianowicie do dzieła Floriana Znanieckiego i Williama Thomasa Chłop polski w Europie i Ameryce (1918), pozwala też na dostrzeżenie ogólnospołecznych problemów, które ze społeczną mobilnością nieuchronnie są związane, a sięgają fundamentów zbiorowego życia. Po pierwsze, w kontekście procesów migracyjnych pojawia się pytanie dotyczące organizacyjnych możliwości grupy pozwalających ograniczać napięcia między indywidualizacją a społeczną spójnością. Dotyczy to zarówno grup macierzystych, jak i zewnętrznych, do których jednostki trafiają. Ważnym spostrzeżeniem autorów przywołanej powyżej pracy jest docenienie roli procesu indywidualizacji w generowaniu nowych form organizacji społecznej i uspołecznienia jednostki. Po drugie, zostaje postawiony problem efektywności działania, w tym także efektywności prób związanych z emigracyjną adaptacją. Otóż dostrzegamy w tym stanowisku silne przekonanie o emergencyjnym charakterze związku między jednostką a grupą i strukturalnym uwarunkowaniami. Pojawiające się problemy niedostosowania, amoralności wyrażają niedostatki bądź wadliwość społecznej organizacji. Po trzecie, dociekania poznawcze nad procesem emigracji dotyczą także szeroko pojętego problemu pracy. Znaniecki i Thomas zwracają uwagę na wzajemne oddziaływania organizacyjnych warunków pracy narzucających dominację wartości ekonomicznych oraz indywidulnych pracowniczych dążności i postaw, które wyrażają znaczenia przede wszystkim charakteru pracy - jej autoteliczną wartość. Zastanawiające zatem jest na ile proces migracyjny jest w stanie wytworzyć struktury organizacyjne rynku pracy, zarówno w kontekście grup docelowej, jak i macierzystej, które pozwalają na zmianę sytuacji pracownika, tak by zbalansować znaczenie roli zawodowej z innymi ważnymi funkcjami pełnionymi w obrębie grupy naturalnej. Trudno zrozumieć zjawisko migracji i doświadczenia ludzi z tym związane bez uwzględnienia ekonomicznego kontekstu, szczególnie kiedy dostrzegamy częstość występowania zarobkowego charakteru decyzji migracyjnych. Po czwarte, pojawiają się ważne pytania dotyczące organizacji kultury będącej wynikiem splotu różnorodnych wartości powstałych w ramach wspólnot narodowych, odmiennych tradycji i stosunków rasowych, a także relacji między mniejszościami a społecznością lokalną. Każde z tych zagadnień oddaje wrażliwość tkanki społecznej na wszelkiego rodzaju sytuacje, w których występuje odmienność, różnica elementów wytwarzających złożony system kulturowy powstały w wyniku pojawiającej się mobilności społecznej. Zagadnienie to wydaje się szczególnie związane z procesem adaptacji i integracji emigrantów w nowych warunkach społecznych. Powraca w tym aspekcie problem 
optymalnej równowagi systemowej dotyczącej kwestii odrębności kulturowej z jednej strony, a z drugiej integracji. Po piąte, Znaniecki z Thomasem podejmują wątek nieuchronnych zmian w rolach kobiety i mężczyzny w warunkach emigracji. Skutkuje to reorganizacją wzajemnych relacji między kobietą a mężczyzną w kontekście różnych grup społecznych oraz sfer życia (choć przede wszystkim dotyczy to życia rodzinnego). Emigracja odgrywa ważną rolę w detradycjonalizacji środowiska rodzinnego, dając również podstawy do zawiązywania się partnerskich układów opartych na współpracy. Po szóste, w rozważaniach autorów Chłopa polskiego w Europie i Ameryce pojawia się interesujący wątek dotyczący społecznego szczęścia. Wskazują oni na potrzebę socjologicznej refleksji nad optymalnymi warunkami ludzkiej egzystencji w środowisku rodzinnym i w świecie pracy. Wydaje się nie bez znaczenia postawienie tej kwestii w kontekście rozważań nad problematyką emigracyjną, gdyż relacja między oczekiwaniami w tym zakresie ze strony jednostki i zbiorowości może zarówno powodować, jak i ograniczać mobilność członków określonych grup społecznych (Znaniecki, Thomas, 1976).

Podsumowując wkład naukowy podstawowych prac empirycznych w polskiej socjologii dotyczących problemu emigracji, możemy wskazać cechy definiujące specyficzność tego typu podejścia teoretyczno-metodologicznego. Otóż zasadniczym założeniem jest wyjaśnienie zjawisk migracyjnych zarówno w kontekście jednostkowych doświadczeń biograficznych osadzonych w strukturach grupowych macierzystego i docelowego środowiska, jak i w szerokim kontekście systemowym z uwzględnieniem wymiaru: kulturowego, instytucjonalno-organizacyjnego, ekonomicznego oraz politycznego. Jak pisze Chałasiński, „,dopiero połączenie obu punktów widzenia i zastosowanie odpowiednich dla każdego metod może dać gruntowne ujęcie naukowe migracji jako zjawiska społecznego” (1936, s. 501). Należy także podkreślić zasugerowany w powyższym cytacie wątek zróżnicowania metodologicznego owego całościowego podejścia. Wykorzystana przez Znanieckiego i Thomasa metoda biograficzna z użyciem dokumentów osobistych (1918), może zostać uzupełniona przez źródła wiedzy o charakterze ilościowym. Nie sposób bowiem unikać analitycznych zabiegów pozwalających na ustalanie określonych regularności statycznych opisujących problematykę emigracyjną. Dwutorowość metodologicznych działań jest istotna, jeśli chodzi o kompletność socjologicznych wyjaśnień. 


\section{BADANIA NAD EMIGRACJĄ POLAKÓW W WIELKIEJ BRYTANII DZIŚ - ZAWĘŻENIE POLA PROBLEMOWEGO}

Określenie wskazanych w tytule problemów związanych z emigracją Polaków w Szkocji wymagaprzejścia do kolejnej fazy analitycznej strategii, która pozwoli na pogłębione spojrzenie na powyżej przedstawione wnioski. Aby móc to uczynić, należy wpierw ustalić obszar zainteresowań badawczych, które pojawiają się w obecnym kontekście społeczno-historycznym, dotyczących migracyjnych strategii życiowych Polaków udających się do Wielkiej Brytanii. Z uwagi na przynależność Szkocji do Zjednoczonego Królestwa i ograniczoną liczbę badań dotyczących omawianego problemu wyłącznie w tym kraju, na tym etapie refleksji zostaną wykorzystane empiryczne ustalenia dotyczące ogólnie Wielkiej Brytanii.

Poszukiwania zorientowane są na odnajdywanie ciągłości dorobku badań nad emigracją oraz elementów będących oznaką dokonujących się przemian cywilizacyjnych generujących „nowe” problemy społeczne. Rekonstrukcję pola problemowego należałoby rozpocząć od wątków związanych z fazową strukturyzacją procesu emigracji. Otóż szczególne znaczenie dla dokonujących się w tym zakresie zmian miał istotny fakt historyczny, jakim było przystąpienie Polski do struktur Unii Europejskiej (2004). Zanik dotychczasowych barier formalnych związanych z przekraczaniem granic państwowych, czyli brak wiz, pozwoleń, skutkuje uwolnieniem potencjału mobilność członków polskiego społeczeństwa, zwłaszcza w warunkach systemowych problemów w kraju. Migracja w tym momencie historycznym, podobnie jak opisuje to Chałasiński, staje się mechanizmem przełamywania izolacji, zarówno w wymiarze jednostkowym, jak i zbiorowym. Zjawisko nasilonej emigracji w tym czasie pełni funkcję swoistej wymiany grupowej - choć w tym przypadku jednostronnej - służącej „,zagospodarowaniu jednostek zbędnych” w jednym układzie społecznym, a przydatnych, nabierających wartości, także dla samego siebie, w innych warunkach (jednak głównie ekonomicznych). Proces akcesyjny włączający Polskę w szerokie struktury związków gospodarczo-politycznych w Europie posłużył również za mechanizm ułatwiający alokacje nie tylko środków produkcji, ale także kapitału pracy, decydując o bardziej optymalnym zbilansowania potrzeb rynku pracy i oczekiwań pracowniczych w niektórych częściach Europy. Na co zwracają uwagę autorzy tekstu Polish Emigration to the UK after 2004; Why Did So Many Come? (Okólski, Salt, 2014), okres między końcem 2003 roku a drugą połową 2005 to czas zdecydowanego wzrostu liczby miejsc zatrudnienia (wolne miejsca pracy ok. 600 tys.) i spadku stopy bezrobocia (4,8\%).

W oparciu o powyższe dane można przyjąć, że zasadniczym motywem emigracji poakcesyjnej jest cel zarobkowy. Jednakże konsekwencje tego faktu mają 
także naturę społeczną, co z perspektywy socjologicznej zdaje się być szczególnie godne uwagi. Związany z ogromną dynamiką wzrostu liczebności Polaków opuszczających nasz kraj i trafiających na Wyspy Brytyjskie (według oficjalnych danych statystycznych UK z 2015 jesteśmy najliczniejszą nacją poza rodowitymi Brytyjczykami) ${ }^{4}$ proces emigracji wchodzi w kolejną fazę instytucjonalizacji i wytwarzania mechanizmów jej towarzyszących. Obnaża to fakt, że polski system społeczny opierający się na różnego typu więziach grupowych - sięgających różnych poziomów organizacja od miko do makro - ma największy problem z integracją młodego pokolenia. Obserwujemy bowiem zdecydowaną nadreprezentatywność młodych ludzi w wieku 20-39 (ze szczególnym wskazaniem na wiek 20-24 lata) wśród wyjeżdżających z kraju (Okólski, Salt, 2014). Oznacza to realne konsekwencje dla grupy pierwotnej, jaką jest rodzina - zarówno jeśli mówimy o tej pozostawionej, jak i o tej, która stanie się najbliższym i zdecydowanie najważniejszym doświadczeniem młodego człowieka. Ten sytuacyjny kontekst stanowi źródło licznych problemów badawczych dotyczących kwestii związanych z funkcjonowaniem środowiska rodzinnego. Możemy zatem mówić o teoretyczno-empirycznych poszukiwaniach dotyczących kondycji życia rodzinnego w warunkach nowego społeczeństwa - rodzi to pytanie o charakter i siłę więzi łączącej członków rodziny, podzielane i przekazywane w procesie wychowawczym postawy i wartości itp. - oraz doświadczeniach indywidualnych poszczególnych członków w odgrywaniu kluczowych ról społecznych. W tym drugim przypadku pojawiają się kwestie związane z byciem mężczyzną, ojcem (ojcostwo), kobietą i matką (macierzyństwo), ale także zagadnienia związane z dzieciństwem i edukacją najmłodszych członków rodziny oraz wspólnie przeżywanymi kryzysami tożsamościowymi. Każda z powyższych sytuacji problemowych znajduje odzwierciedlenie w podejmowanych tematach badawczych socjologicznych prac.

Jeżeli próbowalibyśmy ustalić jakąś główną cechę pojawiającego się obecnie wzorca emigracji - głównie dotyczy to Wielkiej Brytanii - to należałoby zwrócić uwagę na jej generacyjny charakter. Staje się ona ważnym doświadczeniem młodych ludzi wchodzących w dorosłość, którzy są pozbawieni wcześniejszych istotnych doświadczeń zawodowych, jak i rodzinnych. Według danych z badań Krystyny Szafraniec (2010) 64\% trzydziestolatków ma za sobą dłuższy pobyt za granicą, a 37\% wyjeżdżało w celach zarobkowych. Dodatkowo w młodszej kategorii wiekowej dziewiętnastolatków, kiedy pytano ich o plany, 79\% badanej młodzieży deklarowało gotowość do wyjazdu z kraju na rok i dłużej, a 13,5\%

4 Są to dane z ONS - Office for National Statistic UK 2015. Pobrane z: https://www.ons.gov. uk/peoplepopulationandcommunity/populationandmigration/internationalmigration. 
wskazało chęć wyjazdu na stałe. Dane te mogą wzmocnić rozważania dotyczące specyfiki procesu migracyjnego do Wielkiej Brytanii oraz możliwości zaistnienia pokoleniotwórczej roli tego procesu.

W obecnych warunkach globalizującego się świata dynamicznie rozwijający się wymiar komunikacyjny odgrywa znaczącą rolę w generowaniu zmian dotyczących migracji. Łatwość i szybkość przemieszczania w wymiarze geograficznym (związane jest to z coraz niższymi kosztami komunikacji, brakiem barier prawnych, formalnych, poszerzającą się ofertą linii lotniczych itp.) powoduje zmianę społecznego znaczenia przypisywanego zjawisku emigracji. Analogicznie obserwujemy zmiany na poziomie jednostkowych biografii, w obrębie których doświadczenie emigracyjne zyskuje nowy sens. Przyspieszenie powodowane wzrostem społecznych możliwości komunikacyjnych staje się odpowiedzialne za skracanie perspektywy temporalnej, a tym samym redukcję poczucia długotrwałości czy nieodwracalności podejmowanych decyzji. W kontekście emigracji może rodzić się przeświadczenie o tymczasowej nieobecności we własnym środowisku, rodzinie. W tej sytuacji nie następuje zerwanie więzi z rodziną, gdyż emigracja ma zdecydowanie charakter tymczasowy, choć powtarzalny. Możemy w tym przypadku mówić o „migracji wahadłowej”. Tego rodzaju warunki mogą zatem ograniczać potrzebę adaptacji w nowym środowisku, ponieważ silne poczucie tymczasowości może powodować przekonanie o braku funkcjonalności takiego działania. Zatem w przeciwieństwie do emigrantów opisanych przez Znanieckiego, Thomasa czy Chałasińskiego, którzy chcąc zachować więź z grupą macierzystą pozostawioną w kraju, musieli integrować się z rodakami na obczyźnie pochodzącymi często z tej samej wsi, miasta, okolicy, obecnie w warunkach łatwej i szybkiej komunikacji nie jest to konieczne.

Niemniej powyższy opis sygnalizuje użycie dość statycznych wyobrażeń związanych z funkcjonowaniem człowieka na emigracji. Oznacza to bowiem odnalezienie miejsca przywiązania, zakorzenienia jednostki. Czy zatem używając tak określonej perspektywy, możemy sobie wyobrazić człowieka (emigranta) bez użycia kategorii miejsca, a wykorzystując wyłącznie pojęcie ruchu? W konsekwencji przestrzenią definiującą tożsamościowe podstawy ludzkiej egzystencji byłaby podróż między jedną a drugą grupą. Nabrać to może szczególnego znaczenia, gdy mówimy o specyfice środowiska wychowawczego, czyli jeśli od wczesnych lat życia człowiek przyswaja ten rodzaj doświadczania sytuacji emigracyjnej.

Fakt ten każe zastanowić się nad paradygmatycznymi podstawami refleksji nad emigracją, tak by móc dynamikę i jakościową zmienność procesu właściwie odczytać. Ważną rolę w rozpoznawaniu trudno uchwytnych przeobrażeń dotyczących świata społecznego i ludzkich doświadczeń odgrywają metafory, jako 
narzędzia pozwalające związać ze sobą to, co jest już znane i stanowi podstawę zasobu wiedzy, z tym, co postrzegamy jako nowe, niepoddane jeszcze klasyfikacji, naukowemu wyjaśnieniu. Metaforyczność w nauce stanowi pierwszy krok w stronę odkrywania i wyjaśniania zjawisk, które choć wydają się już znane, to zawierają w sobie coraz więcej elementów niewiedzy. Nawiązując do refleksji nad procesem migracyjnym dotyczącym przypadków wyjazdów Polaków do Wielkiej Brytanii, można zastosować użycie trzech zasadniczych metafor przestrzennych obrazujących zróżnicowane formy życia społecznego. Mianowicie są to: regiony, sieci i płyny (Mol, Law, 1994). Każda z tych metafor w odmienny sposób łączy ze sobą kategorie ruchu i miejsca. Pierwsza bowiem, dość dobrze ugruntowana w socjologicznym myśleniu, opiera się na czytelności granic i kontroli społecznej określającej reguły opuszczania i powrotu do macierzystego miejsca. Okazuje wrażliwość na kwestie związane z zakorzenieniem, stabilnością i konsekwencjami opuszczenia bezpiecznego miejsca przywiązania. W drugim przypadku natomiast mamy do czynienia ze sposobem rozumienia przestrzeni, który staje się bardziej wrażliwy poznawczo na relatywność odległości przestrzennych, przy czym kluczowym elementem są tu relacje. Od ich charakteru i siły zależy dystans między elementami w układzie funkcjonalnym, jakim jest sieć społeczna. Przecina ona często granice wyznaczone przez dotychczasowo rozumiane regiony. Natomiast ostatnia z podanych metafor stanowi wyraz dość szczególnego rozpoznania socjologicznego problemu mobilności społecznej. Ukazuje bowiem ograniczoność znaczenia miejsca dla przemieszczania się określonych właściwości za sprawą płynów. Zachowują one swoją konsystencję, gęstość czy lepkość bez względu na bariery, granice, które pokonują. Przekraczając je, dokonują zmiany przy zachowaniu własnej ciągłości (Urry, 2009, s. 45-74).

W konsekwencji należałoby przyjąć, że zrozumienie współcześnie dokonujących się procesów migracyjnych może być wyjaśnione wyłącznie przez wykorzystanie trzech powyższych metafor wpisujących się w różne podejścia paradygmatyczne. Ma to szczególne znaczenie, gdyż pozwala także zrekonstruować zróżnicowanie społeczne, które znajduje swe odbicie właśnie w odmiennych sposobach doświadczania i interpretowania zjawiska emigracji, przy szczególnym uwzględnieniu występowania wewnętrznie niejednorodnych - mieszanych - schematów strukturyzujących kariery biograficzne poszczególnych jednostek.

Ostatnim z wątków wyłaniających się w kontekście porównań między tradycją a współczesnością, kiedy mówimy o problematyce teoretyczno-empirycznego rozpoznania zjawiska czy procesu emigracji, jest kwestia dotycząca płci i ról społecznych z tym związanych. Sięgając do badań Znanieckiego i Thomasa (1918) oraz Chałasińskiego (1936), dowiadujemy się bowiem z jednej strony o postępują- 
cych zmianach dotyczących relacji w ramach ról mężczyzny i kobiety w rodzinie - dotyczy to obecności kobiet na rynku pracy i związanej z tym niezależności ekonomicznej, podziału obowiązków domowych itp. - a z drugiej strony dostrzegamy dość wyraźny wzór emigracji rodzinno-sąsiedzkiej, wyłącznie w którym dopuszczalnym jest, jak pisze Gliwicówna, „wyjeżdżanie staruszek na spokojne zakończenie życia, dzieci, młodych dziewcząt na ożenek [...]” (1936, s. 509). Sytuacja ta ukazuje obecność dużego napięcia między kulturą grupy macierzystej a docelowej, zwłaszcza w kontekście roli społecznej kobiety. Natomiast obecnie możemy mówić - szczególnie w odniesieniu do wyjazdów do Wielkiej Brytanii, gdzie występuje nadreprezentacja ludzi młodych w wieku 20-39 lat przy równoczesnym doreprezntowaniu pod względem płci (Okólski, Salt, 2014) - o zmieniającym się wzorcu emigracji, którego wyrazem jest dynamika mobilności kobiet. Można postawić hipotezę, że stosunek grupy macierzystej do migrujących kobiet w większym stopniu wyraża obecność tradycyjnie zakorzenionych oczekiwań względem roli matki niż roli kobiety. Obserwujemy zupełnie różne konsekwencje wpływów migracyjnych w przypadku analizy roli kobiety i matki, co wydaje się nośnikiem istotnych napięć nieomijających życia rodzinnego.

\section{POLSCY EMIGRANCI W SZKOCJI - WSKAZANIE PROBLEMÓW BADAWCZYCH}

W kontekście dotychczasowej refleksji zarówno nad tradycją, jak i współczesnością badań dotyczących problemów emigracji, możemy podjąć próbę rozwinięcia istotnych zagadnień związanych z wciąż w ograniczonym stopniu empirycznie rozpoznanym przypadkiem Polaków wyjeżdżających do Szkocji. W warunkach rozpoczynającego się procesu Brexitu nabiera to szczególnego znaczenia, zwłaszcza że obserwujemy silne tendencje do autonomizacji Szkocji względem Zjednoczonego Królestwa oraz funkcjonowania w strukturach europejskich (bycie członkiem Unii Europejskiej, pomimo opuszczenia jej przez Wielką Brytanię). Wyraża to równocześnie chęć samodzielnego - niezależnego od Wielkiej Brytanii - kształtowania polityki migracyjnej w najbliższym okresie. Może to także wiązać się z mniej krytycznym nastawieniem społeczeństwa szkockiego do imigrantów, szczególnie w kontekście czynników demograficznych (np. starzejącego się społeczeństwa).

Podstawowym zatem pytaniem staje się to dotyczące problemu pozostania bądź powrotu Polaków do kraju w obecnych warunkach dokonujących się przemian politycznych w Wielkiej Brytanii. Wątek badawczy jest więc skoncentrowany, 
z jednej strony, na kwestii reemigracji, a z drugiej na adaptacji imigrantów do nowej rzeczywistości - do grupy docelowej. Jeżeli chodzi o zagadnienie reemigracji, należy zwrócić uwagę na fakt, że rodzi ono różnego typu problemy, nierzadko wewnętrznie sprzeczne. Otóż nieuchronnym pytaniem związanym z reemigracją jest to dotyczące możliwości modernizacyjnych środowiska macierzystego ludzi powracających do kraju, z uwagi na prawdopodobny zgromadzony kapitał ekonomiczny, ale także, a może przede wszystkim, kapitał kulturowy. Pozostawiony w okolicznościach emigracyjnych system społeczny, który nie posiadał mechanizmów rozwiązujących problem izolacji określonych obszarów własnej struktury, może zostać zreorganizowany, „uzdrowiony” za sprawą czynników zewnętrznych transferowanych z udziałem własnych obywateli. Jednakże aby mogło to nastąpić, musiałaby się pojawić wzmożona aktywność reemigracyjna Polaków do kraju, na drodze której, jak sami wskazują, stoi problem właśnie owego braku zmian modernizacyjnych. Oznacza to, że podjęcie ewentualnej decyzji o powrocie uzależniają oni od zmiany obecnych warunków - np. związanych z aktywnością gospodarczą barier formalnych i obciążeń podatkowych itp. - na bardziej sprzyjające własnej aktywności, najczęściej gospodarczej, zawodowej.

Powyższa sytuacja wskazuje na pojawiające się napięcie skutkujące swoistym impasem. Pytamy bowiem, kto ma ową modernizacyjną zmianę zainicjować, skoro każda ze stron, podmioty odpowiedzialne za porządek prawny i osoby myślące o reemigracji, swoje oczekiwania uzależniają od wcześniejszego działania drugiej ze stron tej złożonej relacji. Najgorszym z możliwych scenariuszy jest ten, który polegałby na sytuacji niespełnienia oczekiwań żadnej ze stron, w kontekście wymuszonych czynnikami zewnętrznymi (np. Brexitem) decyzji o reemigracji.

W pytaniu o wkład modernizacyjny środowiska macierzystego ludzi reemigrujących nie bez znaczenia są pewne doświadczenia historyczne. Sięgając bowiem do literatury przedmiotu, dowiadujemy się, że jeśli chodzi o częste i na dużą skalę migracje Polaków w Europie i Ameryce w XX wieku nie zaobserwowano powodowanych nimi modernizacyjnych przemian społecznych. „Reemigranci nie stanowią więc elementu rewolucjonizującego lokalne stosunki, nowinki przez nich kolportowane przyjmowane były z oporami, a oni sami szybko wracali do utartych obyczajów” (Bukraba-Rylska, 2012, s. 44). Autorka przywołanego cytatu stawia także pytanie dotyczące ciągłości zaobserwowanych wcześniej tendencji. Innymi słowy, czy występują one również współcześnie, czy uległy zanikowi. W oparciu o analizę przeprowadzonych badań stwierdza, że owe tendencje zachowały swoją trwałość i żywotność. „Migracje zarobkowe służą zatem jedynie utrzymaniu dotychczasowego poziomu konsumpcji i zapobieżeniu socjalnej 
degradacji, nie są natomiast motorem rozwoju indywidualnej ani tym bardziej lokalnej przedsiębiorczości. Tym samym okazują się czynnikiem sprzyjającym nie modernizacji, lecz stagnacji [...]” (Bukraba-Rylska, 2012, s. 45). Oznacza to tym samym, że proces migracyjny w sposób naturalny nie rekonstruuje ani systemu kulturowego, ani strukturalnego porządku w macierzystej społeczności. Można mu wręcz przypisać funkcję reprodukcyjną dla obowiązującego systemowego układu społecznego.

Poszukując zatem czynników mogących wpływać na rozstrzygnięcie przeżywanego przez emigrantów dylematu „wracać czy zostać” (a jeżeli tak, to na jak długo), w ramach ustalonego wcześniej wzoru emigrowania możemy przyjąć, że decydującym bodźcem jest środowisko rodzinne i troska o los własnych dzieci. Istotnym elementem strukturyzującym czasowo długość pobytu poza granicami ojczystego kraju jest okres edukacyjny potomstwa. Z uwagi na znaczące różnice w systemie kształcenia w Polsce i Szkocji, rodzice, chcąc uchronić dzieci przed kolejnym trudnym doświadczeniem adaptacyjnym (Moskal, Sime, 2016), podejmują albo planują podjąć decyzję o powrocie bądź przed rozpoczęciem nauki szkolnej dzieci, bądź po jej zakończeniu (chodzi o ukończenie pewnego etapu szkoły podstawowej lub średniej). Zatem w przypadku migracji rodzinnych możemy mówić o większej przewidywalności działań również w odniesieniu do planów powrotu lub przedłużenia pobytu poza granicami własnego kraju.

Z uwagi na obecną sytuację rozpoczynającego się procesu opuszczania przez Wielką Brytanię struktur Unii Europejskiej możemy zakładać zmiany sytuacji imigrantów w tym kraju (w Anglii, Szkocji, Walii i Irlandii Północnej), gdyż ten element był jednym z zasadniczych argumentów na rzecz Brexitu podejmowanym przez znaczną część społeczeństwa brytyjskiego. Obok zmieniających się nastrojów społecznych należy także oczekiwać zdecydowanych ograniczeń prawnych dotyczących napływu imigrantów, dotyczących np. wiz, pozwoleń na pracę itp. W nawiązaniu do dotychczasowych doświadczeń migracyjnych ukazujących proces instytucjonalizacji i fazowość możemy przyjąć, że w powyższych okolicznościach może pojawić się etap emigracji nielegalnej do Wielkiej Brytanii. Odnosić się to może zarówno do osób planujących opuszczenie ojczystego kraju, jak i tych, którzy będą podejmować próby kontynuacji emigracyjnego pobytu, nawet kiedy przestanie to być legalne. Na rozwój takiej sytuacji wpływać mogą wciąż lepsze perspektywy zawodowe, życiowe od tych krajowych oraz wyższe niż dotychczasowe koszty adaptacji, na przykład dotyczące zakupu mieszkania na kredyt. Analizując problem w kontekście ekonomicznym, należałoby uznać funkcjonalność zjawiska emigracji zarobkowej tak dla samych zainteresowanych, jak i kraju ich docelowego wyjazdu. Rodzi się zatem ważne pytanie o zarysowu- 
jące się napięcia między ekonomicznymi korzyściami a społecznymi kosztami, które nasilą się w warunkach wzmożonej kontroli i ograniczeń emigracyjnych w Zjednoczonym Królestwie. Nawiązując do Mertonowskiej koncepcji funkcji jawnych i ukrytych (Merton, 2002), można przyjąć, że proces migracji w kontekście przemian politycznych związanych z Brexitem będzie owocował wyłanianiem się funkcji ukrytych wymagających socjologicznej refleksji.

Jeżeli natomiast powrócimy do problemu adaptacji polskich emigrantów w Szkocji, to w nawiązaniu do tradycji socjologicznej badania tego problemu należałoby przyjąć, że o społeczności Polaków funkcjonujących poza grupą macierzystą powinniśmy mówić jako o emergentnej formie w sensie kulturowym, czyli w tym przypadku jako o społeczności polsko-szkockiej. Zastanawiającym jest jednak zakres tej formy adaptacji, tzn. czy jest ona pełna, czy częściowa oraz jaką rolę w jej kształtowaniu odgrywa upływający czas. Trzeba też podkreślić, że w tym przypadku społeczności polskie na emigracji stanowiłyby one swoistą hybrydę kulturową, która w swej formie nie jest dokładnym odbiciem ani porządku aksjonormatywnego grupy macierzystej, ani docelowej. Czy jednak w tym konkretnym przypadku możemy mówić o takiej formie zbiorowej organizacji? Otóż trzeba docenić rolę czasu, który jest niezbędny w przypadku doświadczeń samych emigrantów. Wiąże się to z koniecznością przyswojenia podstawowej kompetencji dającej możliwość funkcjonowania w nowym porządku symbolicznym, jakim jest język. Jeżeli możliwym ma się stać rzeczywisty kontakt z kulturą kraju, w którym przebywają emigranci, to koniecznym jest pozyskanie umiejętności komunikacyjnych będących nie tylko nośnikiem bieżących informacji, ale przede wszystkim stanowiących narzędzie transmisji kulturowego porządku. Jak wskazują badania, potrzebny w tym celu jest okres od pięciu do siedmiu lat nauki i posługiwania się językiem obcym, choć jest to także uzależnione od wielu innych czynników społecznych oraz indywidualnych (Hakuta, Butler, Witt, 2000). Zatem jeżeli analizujemy problem polskiej emigracji w Szkocji, która w głównej mierze jest migracją poakcesyjną możemy mówić dopiero o wyłanianiu się nowej formy społeczno-kulturowej stanowiącym podstawę dążności, wartości i postaw polskiej emigracji.

Zjawisko emergentnego wytwarzania porządku kulturowego (polsko-szkockiego) może być najbardziej widoczne w przypadku młodego pokolenia, które z uwagi na specyficzne związanie kontekstu społeczno-kulturowego emigracji z procesem rozwoju człowieka - kształtowanie tożsamości - doświadcza wielu sytuacji konfliktowych. Dotyczy to rozbieżności między światem szkoły (szkockiej) a domem rodzinnym (polskim). Warunki te wytwarzają szczególny rodzaj adaptacji, którego zwieńczeniem staje się tożsamość transnarodowa, mogąca 
przyjmować zróżnicowaną postać wyrażającą wewnętrzny układ identyfikacji lokalnych, narodowych i globalnych (Moskal, 2014; Moskal, Sime, 2016).

Analizując wątek tożsamościowy w kontekście zagadnienia adaptacji, należy także zwrócić uwagę, że, jak podaje Bukraba-Rylska, możemy mówić także o sytuacji, kiedy:

mimo cyklicznego przemieszczania się z Polski na Zachód nie można w żaden sposób powiedzieć, by badani czuli się zagubieni, zdezorientowani czy rozdarci między dwoma porządkami kulturowymi. Silne przywiązanie do rodzinnych realiów sprawia, że wcale nie wytworzyła się w nich biwaletna orientacja co do wartości, zasad i norm społecznych (Bukraba-Rylska, 2012, s. 46).

Siła socjalizacji pierwotnej impregnuje takie jednostki przed przyjmowaniem aksjonormatywnego porządku społeczeństwa będącego celem emigracji. Ma to wyrażać wewnątrzsterowność jednostek, które poprzez doświadczenia migracyjne potrafią także wzmocnić swoją samoocenę w oparciu o rosnące poczucie sprawczości. Zaskakujący może być natomiast fakt, że kontakty międzykulturowe, które są udziałem emigrantów, nie muszą w sposób naturalny zmieniać mentalności, stereotypów i autostereotypów, którymi dana osoba posługuje się w codziennych interakcjach. Przywołana powyżej autorka stawia wręcz zaskakującą hipotezę, że „[... [ im dłuższy »staż« migracyjny i intensywniejszy obecny kontakt międzykulturowy, tym większe w danym środowisku nasilenie postaw tradycyjnych” (Bukraba-Rylska, 2012, s. 47). Efektem tego procesu może być fakt nasilania się napięć i konfliktów wpisanych w relacje międzypokoleniowe w środowisku rodzinnym polskich emigrantów, których nie sposób zneutralizować z użyciem dostępnych kulturowych narzędzi zaczerpniętych z grupy macierzystej ani docelowej. W tych warunkach pojawia się przestrzeń do osobistego eksperymentowania z użyciem różnorodnych symbolicznych treści.

\section{PODSUMOWANIE}

Przedstawiona powyżej refleksja dotycząca problematyki migracyjnej we współczesnym świecie, mająca na celu wypracowanie obszarów problemowych będących przedmiotem analizy doświadczeń polskich emigrantów w Szkocji, pozwala na wyciągniecie kilku głównych wniosków. Po pierwsze, socjologiczne spojrzenie na problem emigracji wymaga zarówno dotarcia do znaczenia nadawanego doświadczeniom przez poszczególne jednostki znajdujące się w badanej sytuacji, 
jak i ustalenia strukturalnych uwarunkowań oraz barier, stanowiących systemowy kontekst badanego zjawiska. Po drugie, socjologiczny charakter analizy postawionego problemu wyraża się w tym, że badanie mobilności jednostek dokonuje się z uwzględnieniem przynależności grupowej respondentów i konsekwencji z tego wynikających. Jednostka bowiem występuje jako członek grupy opuszczanej oraz tej, do której wchodzi, ogrywa role oraz zachowuje, zrywa, tworzy więzi społeczne. Wyłącznie w tak określonym społecznym „osadzeniu” człowieka możemy badać problematykę jego migracyjnych doświadczeń. Po trzecie, należy także uwzględnić fakt, że migracja jest procesem, który posiada własną dynamikę, ale również przechodzi przez określone fazy zmian wyrażające utrwalone formy kulturowe w danym okresie czasu. Oznacza to ponadto, że raz wytworzone wzorce kulturowe dotyczące mobilności jednostek i grup społecznych nie dają się nawet poprzez restrykcje prawne wykluczyć z życia społecznego.

Powyższe wnioski mające swe konsekwencje teoretyczno-metodologiczne w podejmowanych próbach badawczych dotyczących analizy współczesnych procesów migracyjnych pozwalają także na wypracowanie problemowych zagadnień systematyzujących refleksje w tym zakresie. Postawione w tekście kwestie związane z problemami: adaptacji, modernizacji społecznej, zmienności w obrębie ról społecznych oraz życia rodzinnego nabierają zupełnie odmiennego znaczenia, gdy zostaną przeanalizowane z uwzględnieniem długiej perspektywy czasowej oraz fazowości dokonujących się zmian. Tak zdefiniowana perspektywa porównawcza daje możliwość wnikliwego rozpoznania przywołanych powyżej dylematów przeżywanych przez migrujące osoby, zarówno w aspekcie subiektywnym, jak i intersubiektywnym czy strukturalnym.

\section{Bibliografia:}

Bukraba-Rylska, I. (2008). Migracje okiem klasyka. Przegląd Humanistyczny, 6, s. 15-30. Bukraba-Rylska, I. (2012). Polskie migrowanie w perspektywie długiego trwania i rozległej przestrzeni. Studia Migracyjne - Przegląd Polonijny, 38 (2(144)), s. 39-56.

Chałasiński, J. (1936). Emigracja jako zjawisko społeczne. Przegląd Socjologiczny, IV, s. 495-501.

D’Angelo, A., Ryan, L. (2011). Sites of socialization - Polish parents and children in London schools. Studia Migracyjne - Przegląd Polonijny, 37 (1(139)), s. 237-258.

Engbersen, G., Leerkes, A., Grabowska-Lusinska, I., Snel, E., Burgers, J. (2013). On the Differential Attachments of Migrants from Central and Eastern Europe: A Typology of Labour Migration. Journal of Ethnic and Migration Studies, 39 (6), s. 959-981.

Garapich, M.P. (2016). London's Polish Borders: Transnationalizing Class and Ethnicity among Polish Migrants in London. Columbia University Press. 
Gliwicówna, M. (1936). Drogi emigracji. Przegląd Socjologiczny, IV, s. 502-520.

Grabowska, I., Engbersen, G. (2016). Social Remittances and the Impact of Temporary Migration on an EU Sending Country: The Case of Poland. Central and Eastern European Migration Review, 2, s. 99-117.

Grabowska, I., Garapich, M.P., Jazwinska, E., Radziwinowiczówna, A. (2017). Migrants as agents of change: social remittances in an enlarged European Union. Basingstoke: Palgrave Macmillan.

Hakuta, K., Butler, Y.G., Witt, D. (2000). How Long Does It Take English Learners To Attain Proficiency? Pobrane z https://eric.ed.gov/?id=ED443275.

Lee, E.S. (1966). A theory of migration. Demography, 3 (1), s. 47-57.

Merton, R.K. (2002). Teoria socjologiczna i struktura społeczna. Warszawa: Wydawnictwo Naukowe PWN.

Mol, A., Law, J. (1994). Regions, Networks and Fluids: Anaemia and Social Topology. Social Studies of Science, 24 (4), s. 641-671.

Moskal, M. (2014a). Language and cultural capital in school experience of Polish children in Scotland. Race, Ethnicity and Education, 19 (1), s. 141-160.

Moskal, M. (2014b). Polish migrant youth in Scottish schools: conflicted identity and family capital. Journal of Youth Studies, 17 (2), s. 279-291.

Moskal, M. (2016). Spaces of not belonging: inclusive nationalism and education in Scotland. Scottish Geographical Journal, 132 (1), s. 85-102.

Moskal, M., Sime, D. (2016). Polish migrant children's transcultural lives and transnational language use. Central and Eastern European Migration Review, 5 (1), s. 35-48.

Okólski, M., Salt, J. (2014). Polish Emigration to the UK after 2004; Why Did So Many Come? Central and Eastern European Migration Review, 3 (2), s. 11-37.

Praszałowicz, D. (2002). Teoretyczne koncepcje procesu migracji. Przegląd Polonijny, 4, s. 9-40.

Szafraniec, K. (2010). Młode pokolenie a nowy ustrój. Warszawa: Instytut Rozwoju Wsi i Rolnictwa Polskiej Akademii Nauk.

Urry, J. (2009). Socjologia mobilności. Warszawa: Wydawnictwo Naukowe PWN.

Znaniecki, F., Thomas, W.I. (1918). The Polish peasant in Europe and America (T. 1-5). Boston: Gorham Press. 